\title{
Bacterial symbionts and mineral deposits in the branchial chamber of the hydrothermal vent shrimp Rimicaris exoculata: relationship to moult cycle
}

\author{
Laure Corbari $^{1, *}$, Magali Zbinden ${ }^{2}$, Marie-Anne Cambon-Bonavita ${ }^{3}$, \\ Françoise Gaill ${ }^{2}$, Philippe Compère ${ }^{1}$
}

\author{
${ }^{1}$ Université de Liège, Laboratoire de Morphologie Fonctionnelle et Évolutive, Unité de Morphologie Ultrastructurale, \\ Allée de la Chimie, 3, 4000 Liège, Belgium \\ ${ }^{2}$ UMR CNRS 7138 'Systématique, Adaptation et Evolution', Université Pierre et Marie Curie, 7 Quai St Bernard, Bâtiment A, \\ 75252 Paris Cedex 05, France \\ ${ }^{3}$ Laboratoire de Microbiologie et Biotechnologie des Extrêmophiles, IFREMER, Centre de Brest, BP 70, 29280 Plouzané, France
}

\begin{abstract}
The shrimp Rimicaris exoculata is considered a primary consumer that dominates the fauna of most Mid-Atlantic Ridge hydrothermal ecosystems. The shrimps harbour in their gill chamber an important ectosymbiotic community of chemoautotrophic bacteria associated with iron oxide deposits. The settlement and development of this ectosymbiosis was investigated using microscopy techniques (light microscopy, LM; and scanning, transmission and environmental scanning electron microscopy: SEM and ESEM, respectively) for shrimps from 2 different vent fields (Rainbow, $36^{\circ} 14.0^{\prime} \mathrm{N}$ and $\mathrm{TAG}, 26^{\circ} 08.0^{\prime} \mathrm{N}$ ). The results revealed a bacterial re-colonisation after each exuviation and a development of the bacterial community in 5 steps in relation to the moult stages, which were used as a reference time scale. In 287 shrimps from both vent fields, pre-ecdysial stages prevailed in the population, suggesting a short anecdysis and high moulting rate, probably to renew the ectosymbiosis. Comparisons with moult cycles of littoral shrimps suggest that the interval between successive exuviations in $R$. exoculata may be as short as $10 \mathrm{~d}$. The colours of $R$. exoculata result from accumulation of iron oxide, which forms a bacteria-associated mineral crust in the gill chambers. The close correspondence between moult stages, the development of the ectosymbiont community and shrimp colours indicate that colour could be used to rapidly determine shrimp moult stages.
\end{abstract}

KEY WORDS: Hydrothermal vents $\cdot$ Shrimp $\cdot$ Moult cycle $\cdot$ Ectosymbiosis $\cdot$ Iron oxides Resale or republication not permitted without written consent of the publisher

\section{INTRODUCTION}

The discovery of deep-sea hydrothermal vents in 1977 revealed many new animals that derive their nutrition from chemoautotrophic bacteria, housed in a variety of tissues and structures (Cavanaugh et al. 2006). The caridean hydrothermal vent shrimp Rimicaris exoculata (Williams \& Rona 1986) is one species that dominates the fauna at several Mid-Atlantic Ridge (MAR) vent sites. It forms large swarms on the chimney walls, reaching densities of up to 2500 ind. $\mathrm{m}^{-2}$ (Desbruyères et al. 2001). $R$. exoculata possesses an enlarged gill chamber, housing an abundant community of bacteria, mostly distributed on bacteriophore setae of the shrimp mouthparts (i.e. scaphognathites, exopodites of the first maxilliped) and on the inner side of the gill chamber (Casanova et al. 1993). Although several morphotypes have been observed in electron microscopy, the bacteria are described as a monoculture of a single phylotype of epsilon-Proteobacteria (Polz \& Cavanaugh 1995). Their appearance, abundance, and attachment to the cuticle suggest an ectosymbiosis (Van Dover et al. 1988, Casanova et al. 1993, Segonzac et al. 1993). Several studies (Wirsen et al. 1993, Polz \& Cavanaugh 1995) suggesting that the bacterial symbionts acquire energy from sulphide oxidation 
have not been experimentally confirmed. The definitive role of these bacteria has still not been clarified, although ectosymbionts have often been considered part of the shrimp diet. Shrimp could feed directly on the bacterial ectosymbionts by grazing on them inside the gill chamber, as indicated by stable isotope measurements (Gebruk et al. 1993, Rieley et al. 1999), but the bacteria in the shrimp mid-gut have also been proposed as an alternative nutritional source (Pond et al. 1997, Polz et al. 1998, Zbinden \& Cambon-Bonavita 2003).

In previous studies the presence has been observed of red-brown mineral deposits in the gill chamber of Rimicaris exoculata, including mouthparts and branchiostegites (Gloter et al. 2004, Zbinden et al. 2004). These deposits have been identified as hydrous iron oxide in the form of ferrihydrite (Gloter et al. 2004). Because of their close association with the bacterial cell walls, these minerals have been hypothesised to result from bacterial metabolism, suggesting, therefore, the presence of chemoautotrophic iron-oxidisers among the bacterial community (Zbinden et al. 2004). Macroscopically, these iron oxides deposited in the gill chamber generate different shrimp colours (Zbinden et al. 2004). For instance, shrimps from the Rainbow vent site exhibit rusty or red hues, while those from the TAG vent site appear mostly dark or black and rusty brown (Gebruk et al. 1993, Zbinden et al. 2004). Changes in iron oxide organization, structure, and abundance are probably responsible for these colour changes.

Zbinden et al. (2004) described 3 bacterial morphotypes (rods, thin and thick filaments) and mapped these bacteria and associated minerals within the whole gill chamber, including the mouthparts, by subdividing the chamber into 3 functional compartments
(Fig. 1), considered as distinct microenvironments: (1) the lower pre-branchial chamber, which houses bacteria but few minerals, (2) the true branchial chamber, which contains the gills but is free of bacteria and minerals, and (3) the upper prebranchial chamber, housing most of the bacteria and associated minerals. Zbinden et al. (2004) were the first authors to suggest that the abundance of bacteria and associated minerals could be related to the shrimp moult cycle, because the bacteria are directly attached to the cuticle which is shed at ecdysis and subsequently renewed, as is the case in all arthropods (Drach 1939; see review in Charmantier-Daures \& Vernet 2004, Compère et al. 2004). Thus, bacterial re-colonisation must occur after each exuviation.

The aim of the present study was to follow the bacterial re-colonisation of the gill chamber and the progress of the mineral-bacteria association between 2 successive moults, in Rimicaris exoculata shrimps from 2 MAR hydrothermal vent sites, Rainbow and TAG. These observations have been related to the moult stages and the external colour of the shrimps, in an attempt to provide a relative and/or an absolute time scale for bacterial colonisation and mineral deposition.

\section{MATERIALS AND METHODS}

Shrimp collection. Specimens of Rimicaris exoculata (Williams \& Rona 1986) were collected during the French 'EXOMAR' cruise (August 2005) to the Rainbow $\left(36^{\circ} 14.0^{\prime} \mathrm{N}, 2300 \mathrm{~m}\right.$ depth) and TAG $\left(26^{\circ} 08.0^{\prime} \mathrm{N}\right.$, $3600 \mathrm{~m}$ depth) hydrothermal vent sites on the MAR. A suction sampler on the ROV (remotely operated
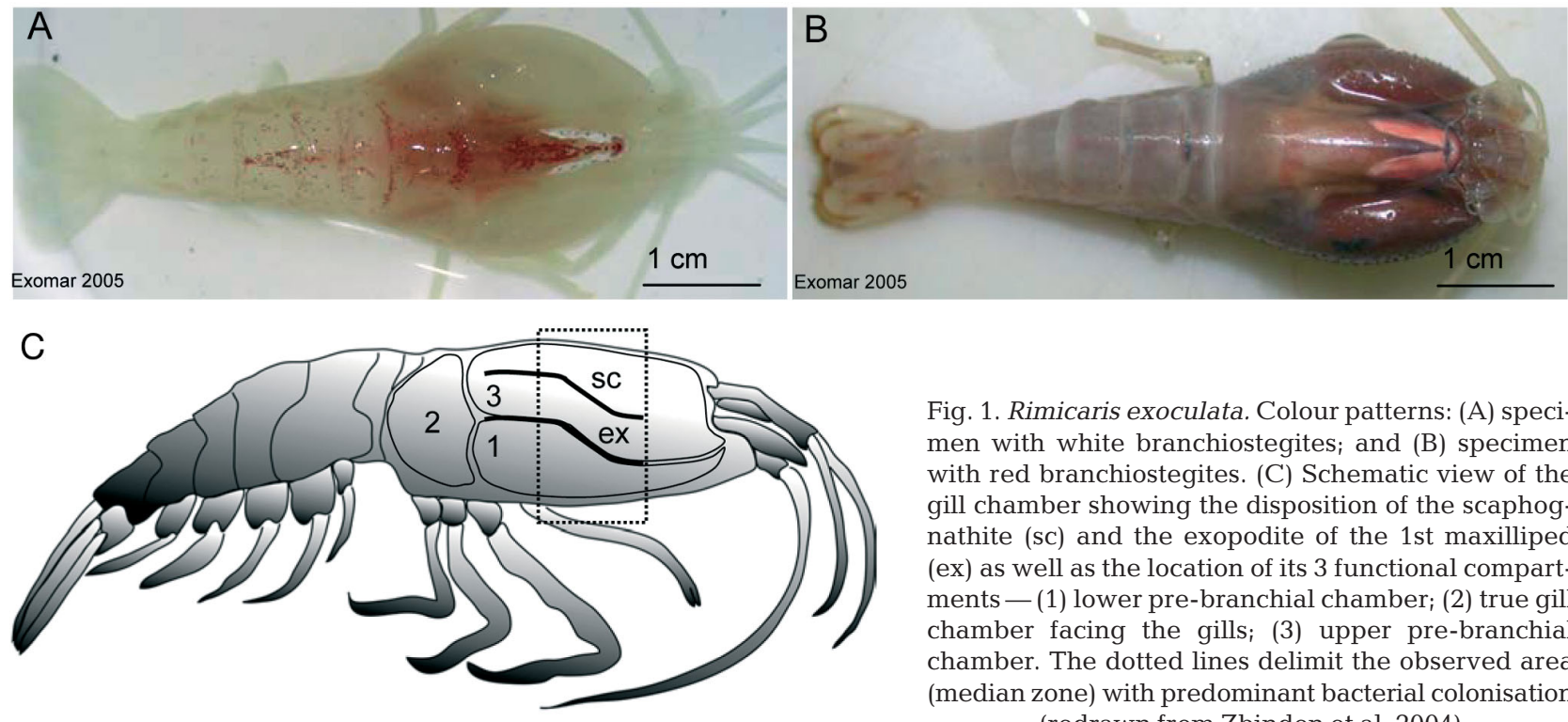

Fig. 1. Rimicaris exoculata. Colour patterns: (A) specimen with white branchiostegites; and (B) specimen with red branchiostegites. (C) Schematic view of the gill chamber showing the disposition of the scaphognathite (sc) and the exopodite of the 1st maxilliped (ex) as well as the location of its 3 functional compartments - (1) lower pre-branchial chamber; (2) true gill chamber facing the gills; (3) upper pre-branchial chamber. The dotted lines delimit the observed area (median zone) with predominant bacterial colonisation (redrawn from Zbinden et al. 2004) 
vehicle) 'Victor 6000' was used, operating from the RV 'Atalante'. Immediately after retrieval, entire living specimens were dissected into body parts (e.g. branchiostegites, tail) and fixed onboard in a solution of $2.5 \%$ glutaraldehyde in a mixture of seawater (salinity $33 \%$ ) and freshwater (dilution 7/10 at pH 7.2).

Moult stages and colour categories. The moult stages of 143 ind. of Rimicaris exoculata from Rainbow and 144 ind. from TAG were determined according to the Drach \& Tchernigovtzeff (1967) moult-staging method, based on the development of setae matrices along the uropod borders and on the hardness of the new cuticle. According to the common nomenclature in use in decapod crustaceans (Charmantier-Daures \& Vernet 2004), the moult cycle is subdivided into 3 periods: (1) the preecdysis, preceding the shedding of the old cuticle (Stages $D_{0}-D_{1^{\prime}-1 "-1}{ }^{\prime \prime}$ and $D_{2}-D_{4}$ ), (2) the postecdysis (Stages A/B, C) and (3) the anecdysis (Stage $\mathrm{C}_{4}$ ), which is a period of integument stability between 2 successive moults. Sampled shrimps exhibited different colours mainly due to red mineral deposits on the integument and especially in the gill chamber (Fig. 1A). The colour of the telson and uropods (forming the tail plate) was observed on all staged specimens and used to classify individuals into colour categories.

Light and electron microscopic observations were performed on Rimicaris exoculata branchiostegites in an attempt to follow bacterial colonisation and mineral deposition through a moult cycle. In order to compare the bacterial cover in different shrimps, the median zone of the branchiostegite (Fig. 1C) was selected as reference area because it presents a regular bacterial cover and lines both the antero-ventral and anterodorsal compartments (Zbinden et al. 2004). Before preparation for electron microscopy, the complete branchiostegite and samples taken from it were observed and photographed under a stereo microscope (Olympus SZ40).

Light microscopy (LM). Samples from the branchiostegites (median zone) were dissected from individuals representative of each moult stage and both vent sites ( $\mathrm{n}=15$ from Rainbow and $\mathrm{n}=20$ from TAG). These samples were post-fixed in osmium $1 \%$, dehydrated in an ethanol and propylene oxide series and then embedded in epoxy resin (SPI-PON 812). Semi-thin sections were obtained from a Reichert-Jung Ultramicrotome (Ultracut E) using a diamond knife, and were then stained with toluidine blue ( $\mathrm{pH}$ 9.0) for observation using LM (Olympus SZ40).

Scanning electron microscopy (SEM). Branchiostegite samples (median zone) were taken from shrimps from Rainbow $(\mathrm{n}=10)$ and TAG $(\mathrm{n}=15)$ selected as representative of the different moult stages. They were dehydrated through an ethanol series, critical-point dried and platinum coated $(20 \mathrm{~nm})$ in a Balzers SCD-030 sputter-unit before observation using SEM (JEOL JSM-840A) at $20 \mathrm{kV}$ accelerating voltage.

Back-scattered electron imaging (BSE). A more precise investigation of the structure of bacteriaassociated minerals was carried out on polished thin slices (20 to $50 \mu \mathrm{m}$ ) of branchiostegites from Rainbow $(\mathrm{n}=10)$ and TAG $(\mathrm{n}=10)$ specimens. The samples were dehydrated in an ethanol and propylene oxide series, then embedded in epoxy resin (EpoFix, Struers) for geological specimens. Polished thin slices on glass slides were produced by abrasion on diamond disks and were finally mirror polished with a non-aqueous 1 $\mu \mathrm{m}$ diamond suspension (ESCIL, PS-1MIC). The polished thin slices were surrounded by conductive silver paint and then carbon-coated in a Balzers BAF-400 rotative evaporator. Structural observations of the bacteria-associated minerals were performed in an environmental scanning electron microscope (FEI XL30 ESEMFEG), working at 15 to $20 \mathrm{kV}$ accelerating voltages. A total of 30 polished thin slices were imaged by secondary electrons (SE) and back-scattered electrons (BSE).

\section{RESULTS}

\section{Moult stage distributions}

To characterise the moult cycle of Rimicaris exoculata, the moult stages were determined on a total of 287 ind. ( $\mathrm{n}=143$ from Rainbow site and $\mathrm{n}=144$ from TAG site). Sampling is supposed to be random and the massive shrimp collection can be considered as representative of the population. The percentages of individuals (\% ind.) at each moult stage represent their relative proportions within the population and should correspond to the relative duration of the stages in the moult cycle (see 'Discussion'). Results obtained from both Rainbow and TAG populations were pooled because no significant difference was observed between them. Fig. 2A,B shows that more than $80 \%$ of the shrimps were in preecdysis (Stages $\left.\mathrm{D}_{0}-\mathrm{D}_{4}\right)$ with a maximum of $50 \%$ of the individuals at Stage $D_{1}$, the longest moult stage. In contrast, anecdysis (Stage $\mathrm{C}_{4}$ ) accounted for $<10 \%$ of the individuals, likewise, the postecdysial stages (Stages A/B and C). This suggests that $R$. exoculata shrimps spent the major part of their moult cycle in preecdysis, in particular in stage $D_{1}$. A direct comparison with data provided by the literature on other natantia shrimp species suggests that the anecdysial period is shorter in $R$. exoculata than in littoral shrimps (Charmantier-Daures \& Vernet 2004) such as Leander sp. and Penaeus japonicus (Fig. 2C,D, see 'Discussion'). 

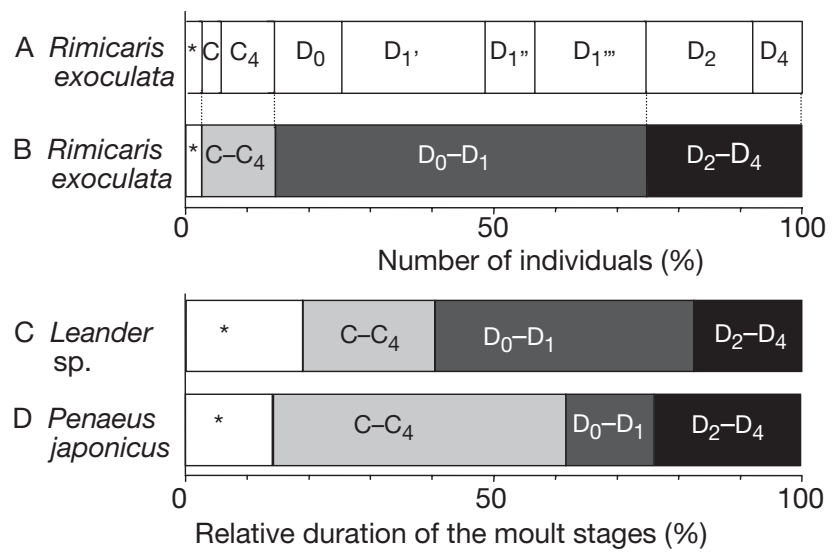

Fig. 2. Rimicaris exoculata. Moult cycle in comparison with that of littoral shrimps. (A) Detailed and (B) compiled results of 287 staging specimens from Rainbow and TAG. Data are expressed in \% of individuals in the population, considered as equivalent to the stage duration in \% of the moult cycle. Relative duration of the moult stages expressed in \% of the moult cycle in (C) Leander sp. shrimps (source: Lindquist 1975) and (D) Penaeus japonicus (source: Charmantier-Daures \& Vernet 2004). ${ }^{*}$ Moult stage $A / B$; light grey: post-ecdysial and anecdysial; grey: re-ecdysial; black: late pre-ecdysial

\section{Moult stages and colours}

As illustrated by Figs. 1 \& 3, specimens of Rimicaris exoculata (from Rainbow and TAG) exhibited different colours, ranging from white and grey to dark red. From macroscopic observations of the colour and abundance of mineral deposits on the branchiostegite inner side and the tail plates, the shrimps were classified into 5 colour categories: white, light red, medium red, dark red and grey (Fig. 3, Panels A, B, C, D and E, respectively); grey was present in TAG specimens only. The correlation between the colour of tail plates and branchiostegites was checked and confirmed in 40 ind. against both parts (Fig. 3). Other individuals were categorised on the basis of the tail plate colour. Combining moult staging and colour categorisation demonstrated that shrimp colours gradually evolved from white to dark red throughout the moult cycle (Fig. 4A,B). All $R$. exoculata shrimps in postecdysis were white, while all the preecdysial individuals from Rainbow and most from TAG were red. Moreover, the progression of the red colour throughout the moult cycle was very obvious on Rainbow specimens. Light red individuals prevailed in Stage $D_{0}(60 \%)$ with medium red individuals $(40 \%)$; the latter then predominated in $\mathrm{D}_{1^{\prime}}$ and $\mathrm{D}_{1^{\prime \prime}}$ (with more than $90 \%$ ). The same gradual progress was true for dark red individuals, which appeared relatively early in $D_{1^{\prime \prime}}$ and increased their proportion up to $55 \%$ at Stage $\mathrm{D}_{4}$, just before exuviation. A similar but less obvious colour scheme throughout the moult cycle was observed in the shrimps from TAG. The only exception were the grey shrimps, which represented a significant proportion of individuals from anecdysis to Stage $\mathrm{D}_{2}$ with a maximal proportion in $\mathrm{D}_{0}$ of up to $40 \%$. These observations revealed that between 2 successive moults, the accumulation of red mineral mainly in the gill chamber of the $R$. exoculata shrimps induced colour changes from white to dark red. A close correspondence could then be established between the colour and the moult stages of the shrimps. The same phenomenon occurred for both Rainbow and TAG individuals, the only differences being that dark red shrimps were less abundant at TAG, and grey shrimps emerged as an additional stage between the white and red specimens.

\section{Bacterial colonisation and growth}

SEM and LM observations of bulk samples and semithin cross sections of the branchiostegite (Fig. 1C) were carried out to determine the bacterial settlement and the mineral deposition in the gill chamber of individuals at different moult stages. Throughout the morphological observations, different bacterial morphotypes previously described (Zbinden et al. 2004) were distinguished: individual rods $(0.5 \times 1.5 \mu \mathrm{m})$ and 2 types of filaments, i.e. thick filaments ( 2 to $3 \mu \mathrm{m}$ in diameter) and thin filaments ( 0.5 to $1 \mu \mathrm{m}$ in diameter). Bacterial colonisation could be divided into 5 steps revealing the successive bacterial morphotypes colonising the gill chamber. These observations were also related to the shrimp moult stages and colour categories. Bacterial and mineral distribution did not differ between individuals from the Rainbow and TAG sites.

Step 1: bacterial settlement. Bacterial settlement was observed on postecdysial specimens, which were entirely white (stages A/B and C), exhibiting only scarce and randomly distributed bacterial patches (Fig. 5A1). Thin filaments and rods were the only morphotypes present and their distribution and arrangement suggested that they were in a multiplication phase. Short filaments of only a few cells appeared which were clearly starting to grow (Fig. 5A2). During this step, no mineral was detected (Fig. 6A).

Step 2: bacterial growth. Specimens in anecdysis (white or light red individuals, stage $\mathrm{C}_{4}$ ) already showed abundant bacterial colonisation, which appeared as an almost continuous dense mat (Fig. 5B1). In some places where the filaments were shorter, rod-shaped bacteria were visible and attached to the cuticle (Fig. 5B2). The bacterial coat consisted mainly of a mixture of long thick and thin filaments (about $250 \mu \mathrm{m}$ in length) but with thin filaments prevailing (Fig. 6B). Rod-shaped bacteria were also visible in a small area (about $100 \mu \mathrm{m}$ width) along the ventral border of the branchiostegite. Being devoid 

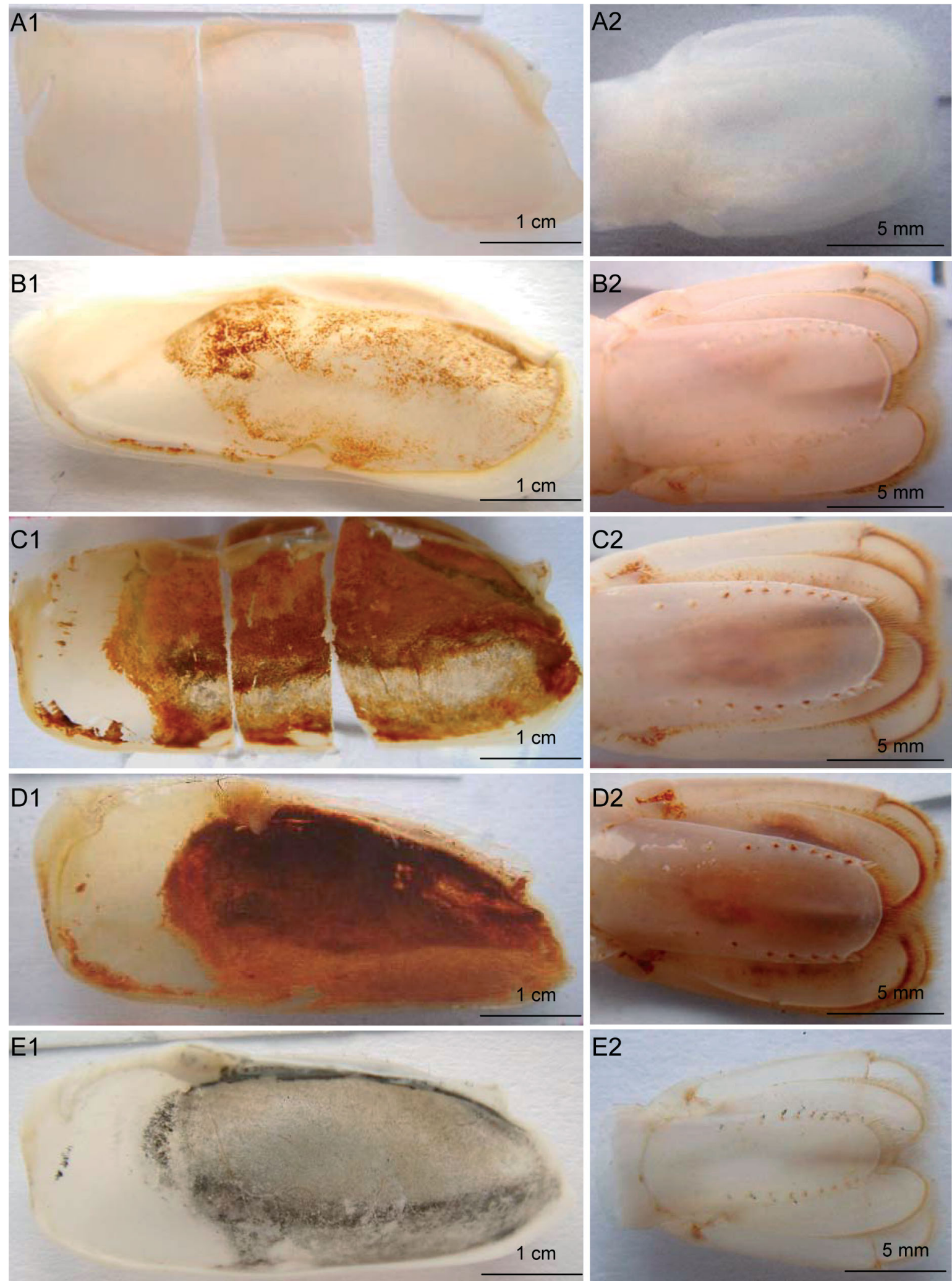

Fig. 3. Rimicaris exoculata. (A-E) Colour categories observed on the inner side of the branchiostegites (1) and on the tail plates (2) and respectively ranged: (A) white, Stage A/B; (B) light red, Moult Stage $\mathrm{D}_{0} ;(\mathrm{C})$ medium red, Moult Stage $\mathrm{D}_{1^{\prime \prime} ;}(\mathrm{D})$ dark red, Moult Stage $\mathrm{D}_{2}$ (E) grey (only observed in TAG specimens), Moult Stage $\mathrm{D}_{0}$. Note the strong colour correlation between branchiostegites and tail plates for same staged individual 


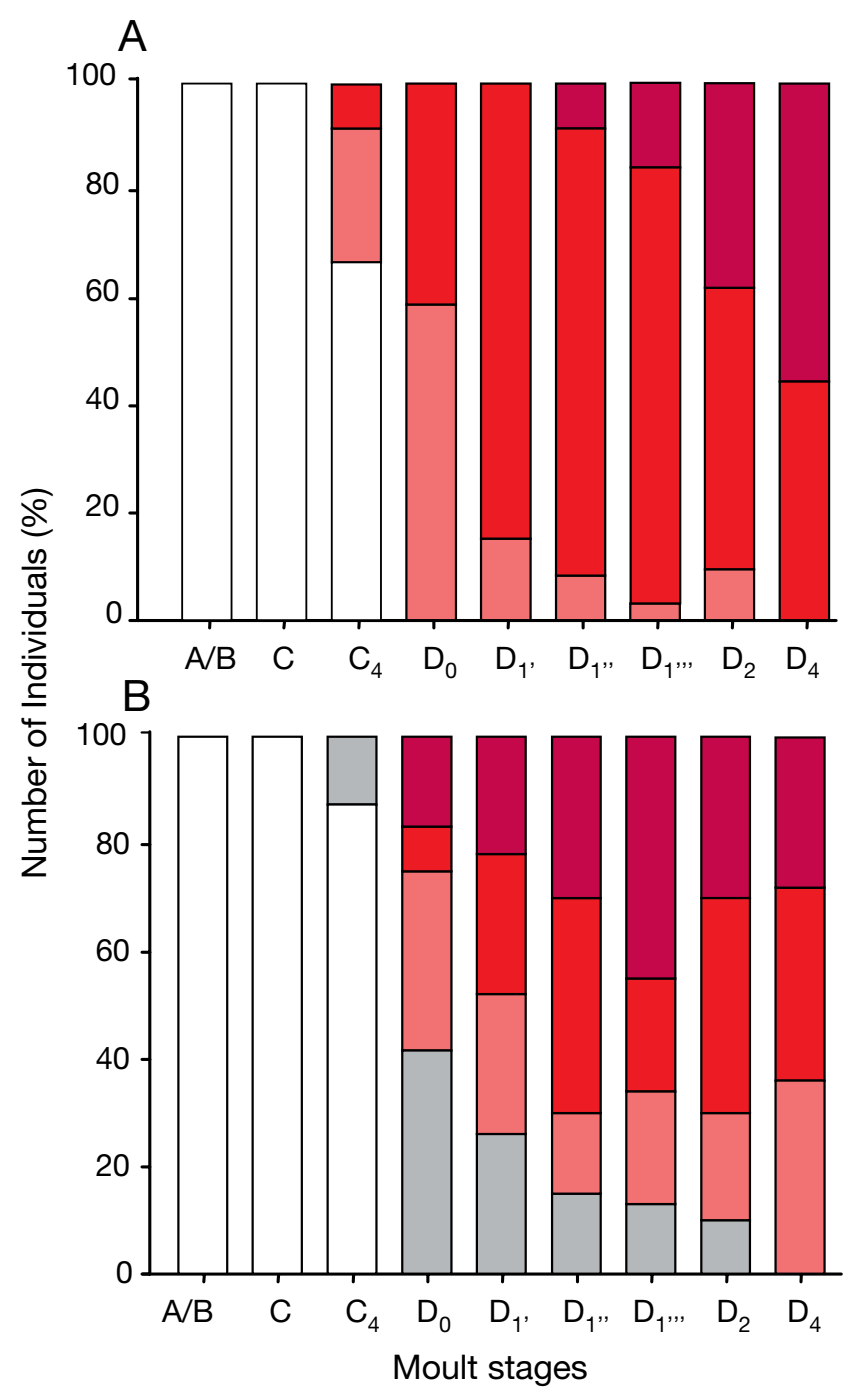

Fig. 4. Rimicaris exoculata. Distribution of coloured individuals at different stages of the moult cycle. Colour categories (white, light red, medium red, dark red and grey) were determined on the tail plates (telson and uropods) of 287 ind. and correlated with the colour of the gill chamber. (A) Specimens from Rainbow site $(n=143)$. (B) Specimens from TAG site $(\mathrm{n}=144)$. Grey individuals only present at TAG site

of filaments, this area (ventral area) was distinguished from the rest of the branchiostegite. At this stage, no mineral particles were visible with SEM and only diffuse and scarce deposits were detected with transmission electron microscopy (TEM; not illustrated).
Step 3: first mineral particles. Maximum bacterial density was observed in early preecdysial individuals (light red or medium red, Stages $\mathrm{D}_{0}-\mathrm{D}_{1}$ ). The inner branchiostegite was totally covered by a thick mat of filamentous bacteria, dominated by thin filaments (Fig. 5C1). In some places, the first mineral particles were distinguishable in SEM through the mat of bacteria (Fig. 5C2). They mainly appeared between the bases of the filaments, as also revealed by the semithin sections (Fig. 6C). These sections clearly showed that most of the mineral particles were near the cuticle. The ventral area was still well delimited, with a dense cover of rod-shaped bacteria, in mono- or bilayers.

Step 4: heavy mineral deposits. At preecdysial Stages $\mathrm{D}_{1}-\mathrm{D}_{2}$ (medium red individuals), the bacterial community showed the same morphological characteristics as those described for the previous moult stage. However, much more mineral was present and formed a more or less continuous layer (Fig. 5D1). Semi-thin sections (Fig. 6D) revealed that mineral particles were no longer close to the cuticle, but were now at some distance from it. The space between the mineral and the cuticle appeared to be filled with bacteria. In SEM, heavy mineral deposits were visible between the bacterial filaments. Thus, mineral seems to be preferentially deposited along thick filaments, resulting in the building of mineral sheaths around them (Fig. 5D2).

Step 5: mineral crust. In dark red individuals, typical of late preecdysis (Stages $\mathrm{D}_{2}-\mathrm{D}_{4}$ ), most of the colonised area of the branchiostegite was coated with heavy mineral deposits (Fig. 5E1, E2), except the ventral part where rod-shaped bacteria always predominated. The mineral deposits formed a continuous compact crust showing some cracks. On the upper surface of the crust, the number of bacteria seemed to be drastically reduced. Thin filaments had almost disappeared and only the top of a few thick filaments still emerged from the surface of the mineral crust (Fig. 5E2). In contrast, the cracks suggest that a rich bacterial population is located inside or below the crust. (Fig. 5E1, Fig. 7A). This was confirmed by observation of the lower side of the mineral crust using SEM, showing numerous thin filaments and rods (Fig. 7). Semi-thin and ultra-thin sections also exhibited an abundant bacterial population under the compact mineral layer (Fig. 6E).

Fig. 5. Rimicaris exoculata. SEM micrographs illustrating the 5 steps of bacterial colonisation on the branchiostegite inner side. (A) First step of bacterial colonisation (rod-shaped and filamentous bacteria) on white individuals in postecdysis. (B) Thin and thick bacterial filaments, on white individuals in anecdysis. (C) Bacterial filament and first mineral deposits close to their basis on light red specimens (Stages $\mathrm{D}_{0}-\mathrm{D}_{1}$ ). (D) Growth of the mineral deposits as sheathes around bacterial filaments (medium red individuals, Stages $D_{1}-D_{2}$ ). (E) Mineral crust with dense coating of bacterial filaments, on dark red specimens in late preecdysis (Stage $\mathrm{D}_{4}$ ). Right-hand column (panels with number '2') gives a higher magnification than the left-hand column (numbered '1') 

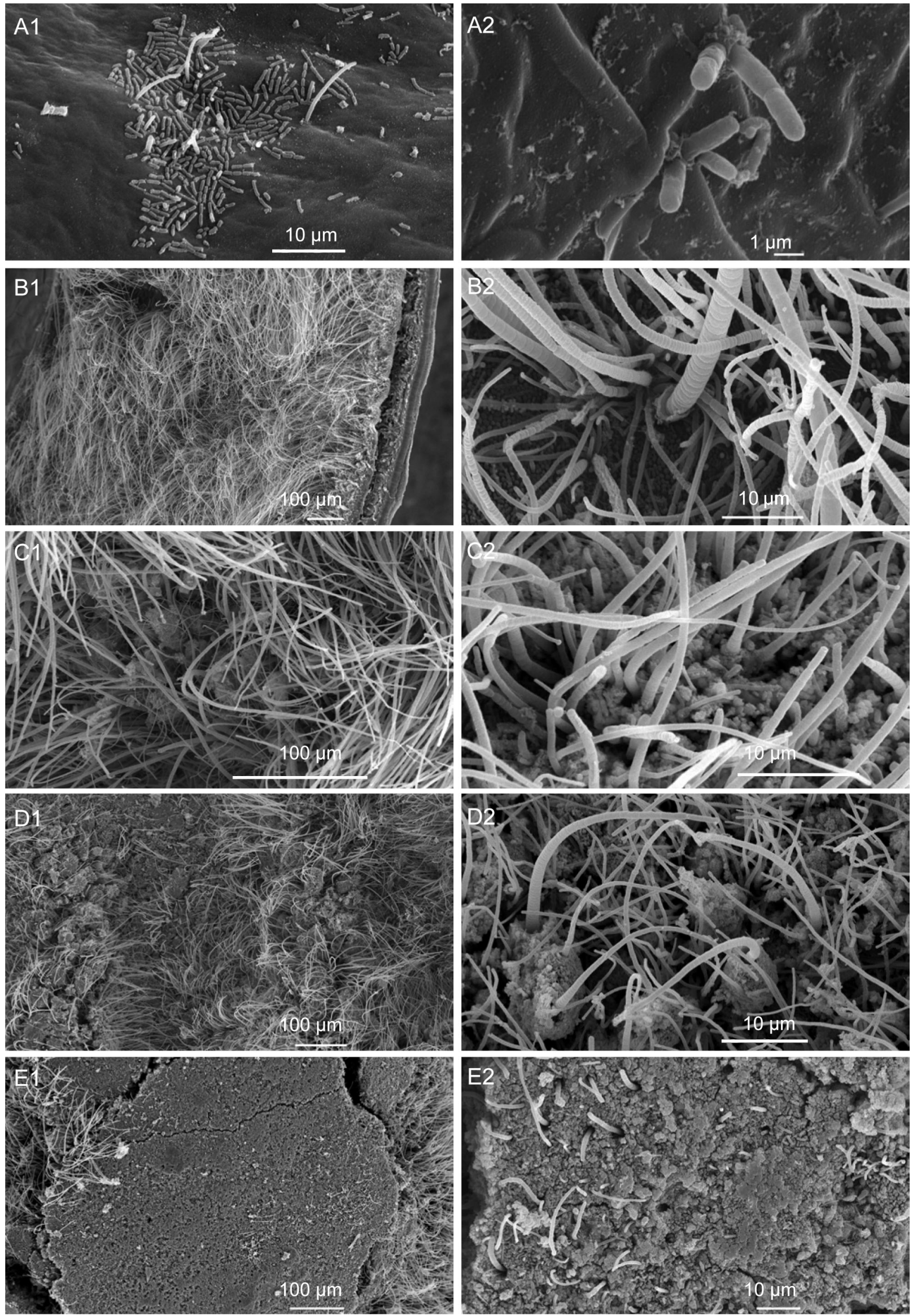
A
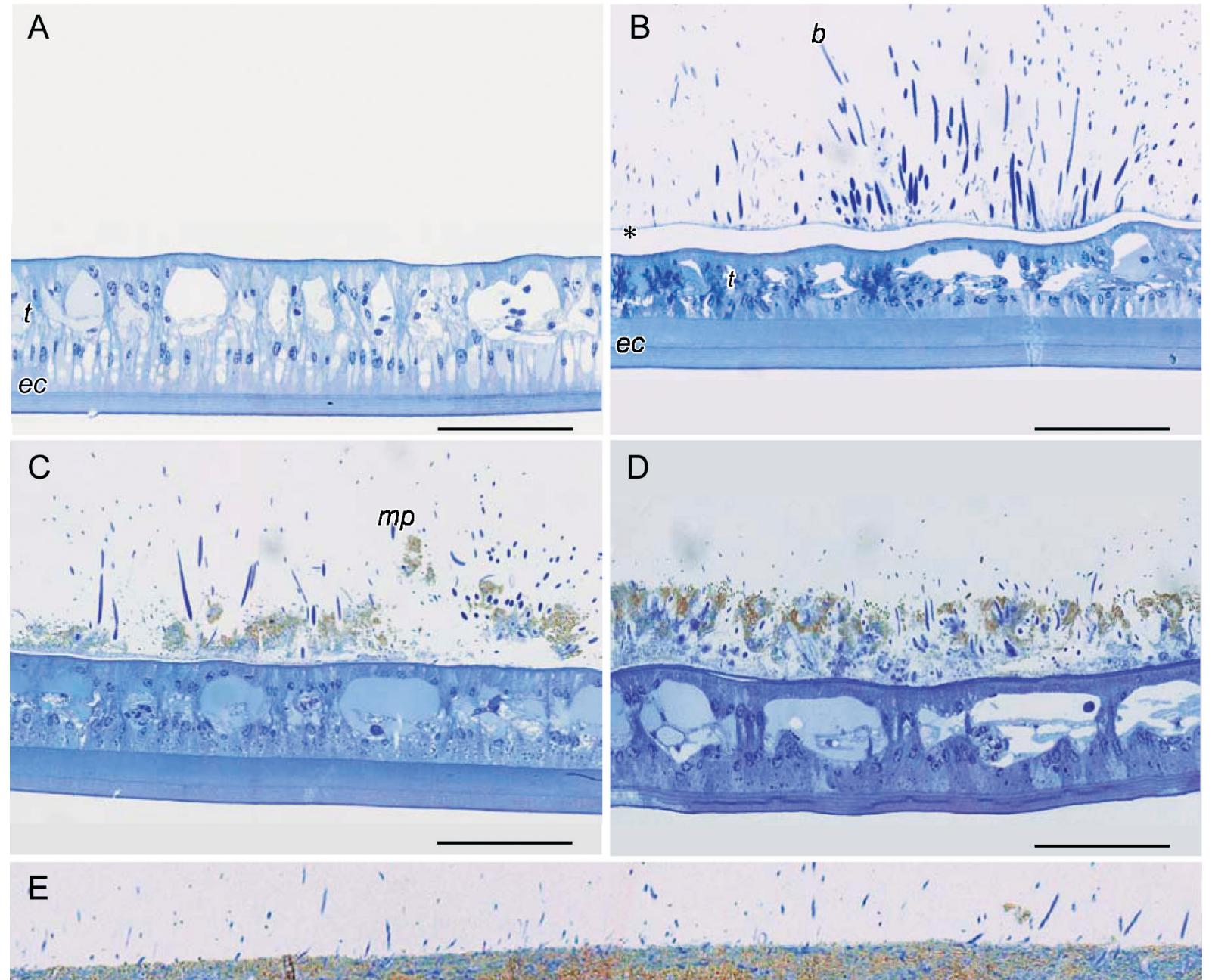

D
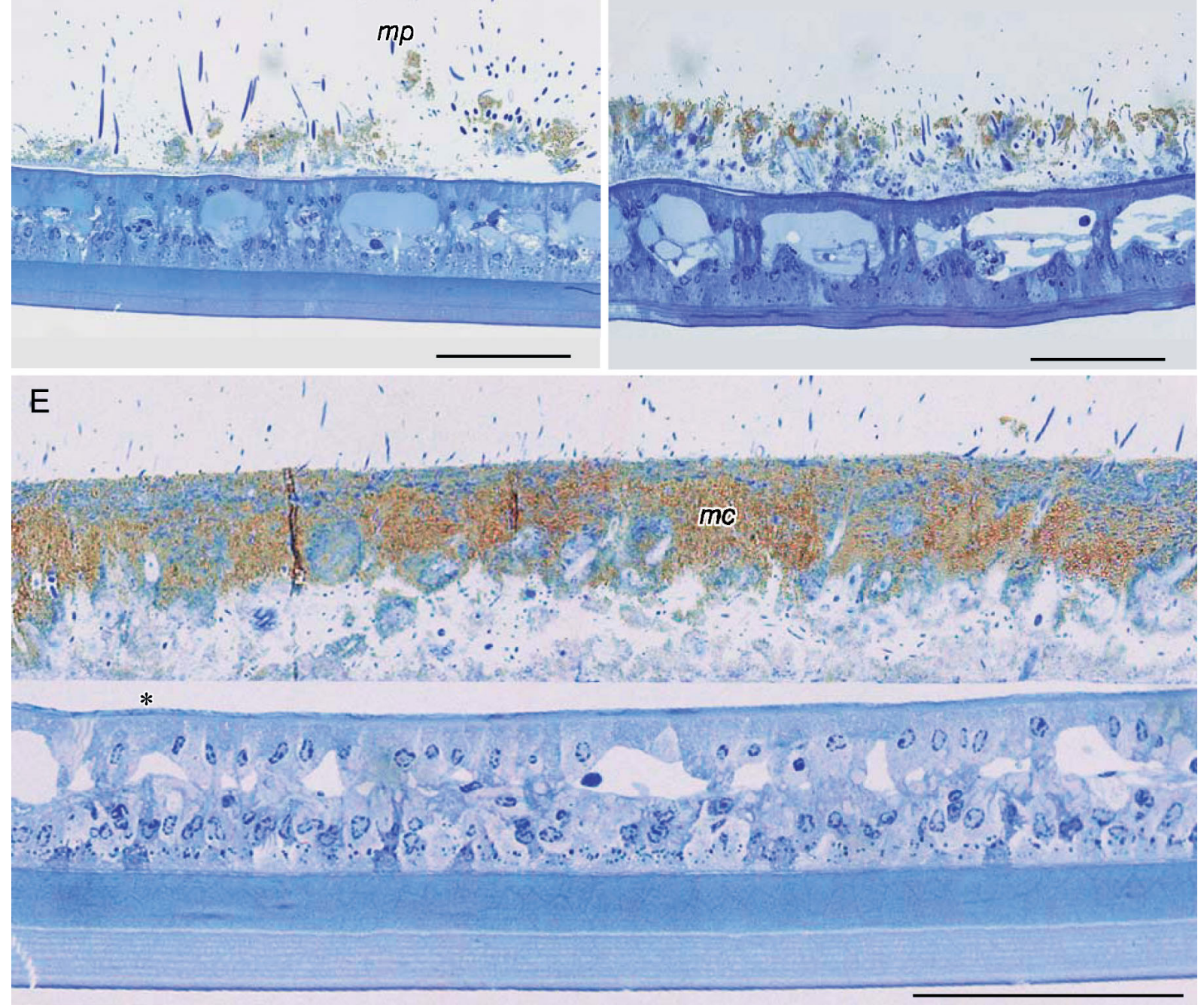

Fig. 6. Rimicaris exoculata. Semi-thin sections of the branchiostegite illustrating the 5 steps of bacterial colonisation and mineral deposition. (A) Branchiostegite totally devoid of bacteria in a white individual in postecdysis. (B) Substantial bacterial cover without mineral deposit in a white individual at Moult Stage $\mathrm{C}_{4}$. (C) Early mineral deposition in a light red specimen at Moult Stage $D_{0}$. (D) Increase of mineral deposits in a medium red specimen in Moult Stage $D_{1}$. (E) Heavy mineralised layer in a dark red individual in late preecdysis. Scale bars: $100 \mu \mathrm{m}$. ec: external cuticle, $b$ : bacteria, $t$ : tissues, $m p$ : mineral particles, $m c$ : mineral crust. 

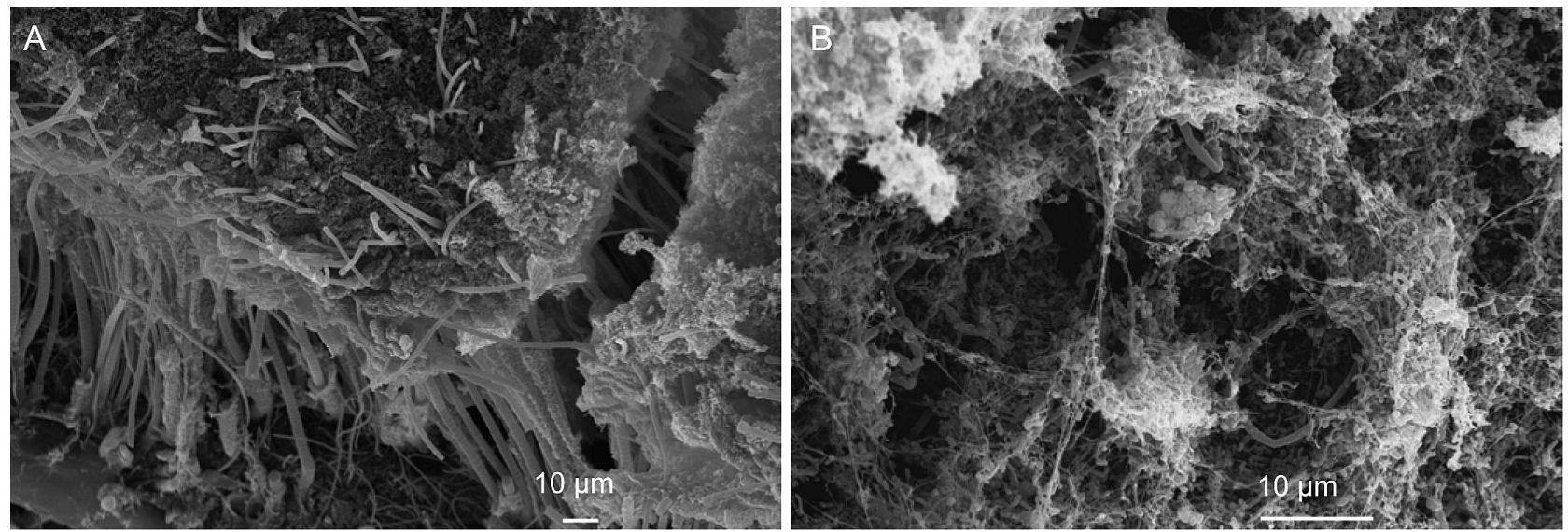

Fig. 7. Rimicaris exoculata. SEM micrographs of the mineral crust. (A) Lateral view with high density of filaments, inside the mineral layer. (B) View of the lower face of the mineral crust covered by a high density of rod bacteria and thin filaments

\section{Mineral deposition and mineral crust formation}

Examination of polished thin slices of the branchiostegite from heavily mineralised individuals in late preecdysis revealed the detailed architecture of the fully formed mineral crust (Fig. 8A). All the most heavily mineralised individuals exhibited a mineral crust of up to $100 \mu \mathrm{m}$ thick. BSE images (giving atomic mass contrast) revealed structural details of the mineral particles that formed the crust, and the smallest particles that could be detected. Together with semi-thin sections, these observations enabled us to distinguish 3 layers in the crust along a mineral density gradient from the cuticle to the surface (Fig. 8A). The upper level, forming approximately the outer half of the crust (about $50 \mu \mathrm{m}$ ), was the most fully mineralised and compact. It consisted of joined but not fused particle units of about $2 \mu \mathrm{m}$ in diameter (Fig. 8B). Neighbouring polygonal particles separated by very narrow spaces (few nm) filled the area. Moreover, the particle section shapes, with deep indentations and globular domes radiating from a massive centre, suggested that these particles resulted from the fusion of several smaller ones. They had a rosettelike shape, growing as spherules until meeting neighbouring particles. Some particles, with a hole in their central region, appeared perforated by a thin bacterial filament. In the same way, the upper level of the crust was regularly perforated by large mineral-free tubes of about $4 \mu \mathrm{m}$ in diameter, corresponding to thick filaments. The median level of the crust consisted of large globular and multiglobular particles (Fig. 8C) which, in contrast to those in the upper layer, were separated by broad spaces. The lower level corresponded to the lower side of the mineral crust, which appeared very rich in bacteria (rods and thin filaments) in SEM (Fig. 7). This zone was also visible on the semi-thin sections (Fig. 6E) between the compact minerals and the cuticle. BSE-images revealed the presence of very fine mineral deposits, not visible either in bulk samples in SEM or in LM. Particle size did not exceed 500 nm (Fig. 8D) and most particles were in contact with the bacteria.

\section{DISCUSSION}

\section{Moult cycle in life environment}

Moult represents the major process which enables crustaceans to grow (Charmantier-Daures \& Vernet 2004). This mechanism is initiated under neuroendocrine control and is influenced by numerous environmental factors (temperature, water salinity or pollutants) that can modify the duration and periodicity of the moult cycle. The usual method of estimating the moult stage duration by continuous observation throughout a moult cycle does not apply to Rimicaris exoculata, because individuals cannot be observed over a sufficiently long period (more than a few hours) either in their natural environment or in a pressurised aquarium such as IPOCAMP (Shillito et al. 2004). In the present study, the relative duration of the moult stages of $R$. exoculata was thus assessed by counting the number of individuals at each stage in as large a sample as possible, i.e. half the specimens collected during the EXOMAR cruise (287 from a total of 599 ind.). Each moult stage has an absolute duration and a relative duration which is a percentage of the absolute total duration of the moult cycle. In addition, under certain conditions, such as rapid asynchronous moults, the relative durations of the moult stages represent pro- 

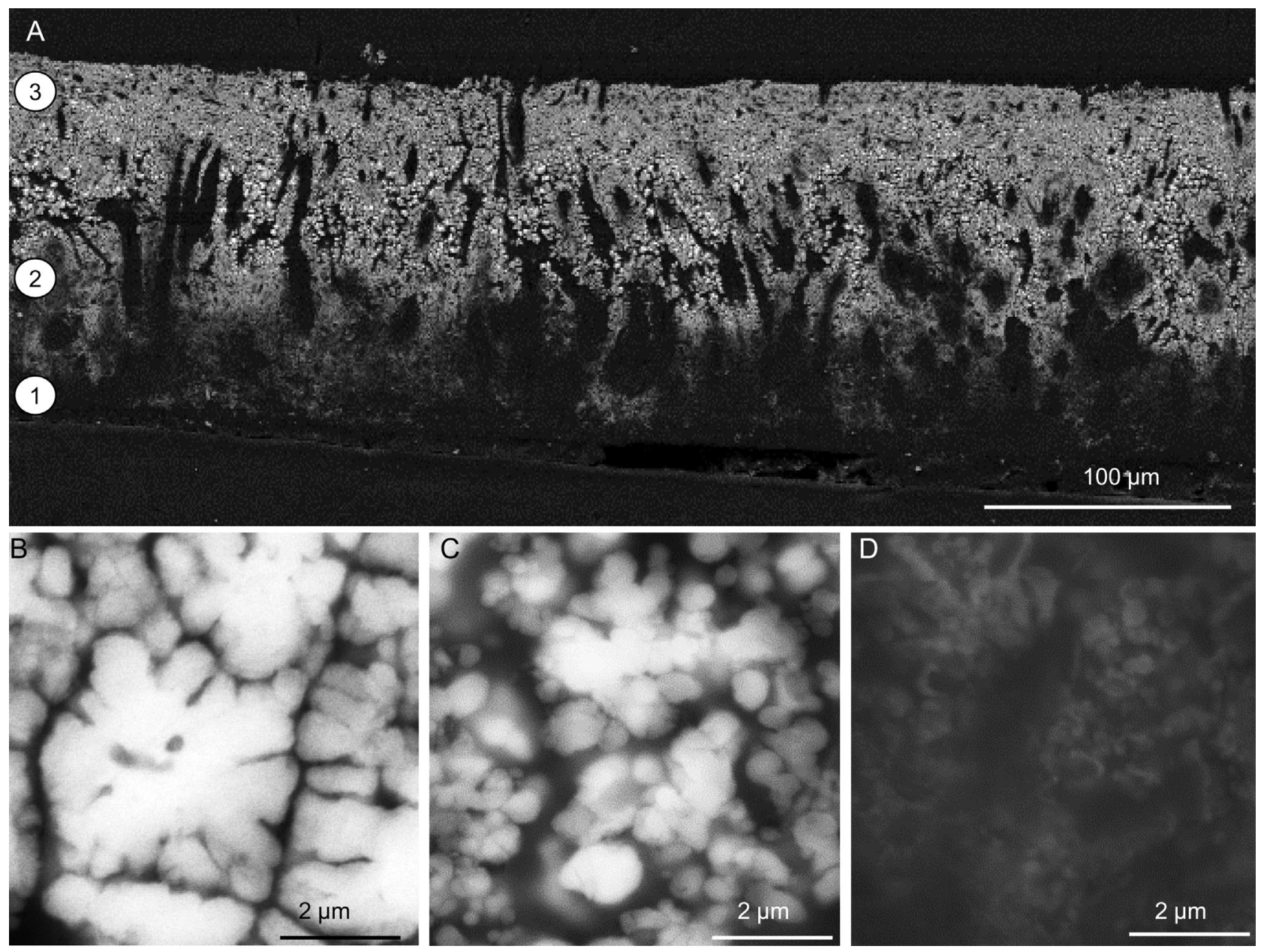

Fig. 8. Rimicaris exoculata. Architecture of the mineral crust in a dark red specimen (Rainbow, Moult Stages $\mathrm{D}_{2}-\mathrm{D}_{4}$ ). $(\mathrm{A}) \mathrm{BSE}$ image of a polished cross-section showing the lower (1), median (2) and upper (3) levels of the mineral crust. (B,C,D) Details of mineral particles: (B) aggregated mineral particles intersected by deep indentations in the upper level, (C) globular or multiglobular particles in median level, and (D) diffuse mineral deposits in lower level

portions of individuals in a population. This is the case, for example, for small crustacean species such as cladocerans (Bottrell 1975, Hessen \& Alstad Rukke 2000), copepods in breeding, or for tropical shrimps or northern shrimps during summer (Benayoun \& Fowler 1980).

Because information on moult stage duration in hydrothermal species is lacking, results can only be compared with data on a few shallow-water shrimps. Results revealed that the great majority (up to $85 \%$ ) of the Rimicaris exoculata shrimps examined were in preecdysis, suggesting that this period occupies more than $80 \%$ of the moult cycle duration. This contrasts with littoral shrimps and other decapod species, where preecdysis is no more than $60 \%$ of the moult cycle in the shrimp Leander sp. (Lindquist 1975), $40 \%$ in Penaeus japonicus and $<20 \%$ in Macrobrachium rosenbergii (Charmantier-Daures \& Vernet 2004). In fact, this surprising result in $R$. exoculata may be the direct consequence of either very short postecdysial/ anecdysial periods or of unusually long preecdysis. Moreover, a similar predominance of preecdysial stages was previously observed, but on small numbers of individuals from the Rainbow and Lucky Strike vent fields ('MARVEL' cruise in 1997 and 'ATOS' cruise in 2001; M. Zbinden \& P. Compère unpubl. data). The possibility that most of the $R$. exoculata specimens were collected at the same period of synchronous moults seems unlikely because of the 'insular character' and persistence over several years of the deep hydrothermal environment, which is not subjected to external or seasonal influences. Also, the very similar proportions of moult stages, in both shrimp populations from sites several thousand kilometres apart, contradicts any hypothesis of synchronous moulting biorythm in the $R$. exoculata populations. The question of a long preecdysis or of a short anecdysis in $R$. exoculata can be excluded as there are abundant literature 
data on Reptantia (crabs and lobsters) and very scarce data on Natantia. Indeed, anecdysis (Stage $\mathrm{C}_{4}$ ) that corresponds to a rest phase of the integument appears to vary considerably in duration, changing with the moulting rate according to environmental parameters, e.g. seasonal conditions and pollutants, or simply with the age and size of individuals (Drach 1939). For example, Stage $\mathrm{C}_{4}$ was reported to be absent in juvenile Carcinus maenas that undergo rapid successive moults whereas it lasted several months in large older specimens (Andrieux 1979). Consequently, differences between high and low moulting rates in Natantia and Reptantia respectively, are generally attributed to variations in the duration of the anecdysis. In contrast, the duration of the preecdysial period is about the same in different species and increases only slightly with the size of individuals and the thickness of their cuticle. Thus, it can be reasonably supposed that preecdysis is relatively short in all species because crustaceans stop eating in this phase (from $\mathrm{D}_{2}-\mathrm{D}_{4}$ ). They also have problems of mobility and vulnerability (because of their 2 cuticles, one old and one new separated by an ecdysial space). This likely applies to $R$. exoculata because the digestive tracts of most individuals in late preecdysis and early postecdysis were empty (M. Zbinden \& P. Compère pers. com.). Interestingly, species of similar size and cuticle thickness probably spend about the same time in preecdysis, as it is an essential and non-compressible stage for the synthesis of their new cuticle. By comparison with $P$. japonicus, which spends $8 \mathrm{~d}$ in preecdysis $\left(\mathrm{D}_{0}-\mathrm{D}_{4}\right)$, the absolute duration of the moult cycle of $R$. exoculata can be tentatively estimated by extrapolation at $10 \mathrm{~d}$, i.e. much shorter than that of $P$. japonicus $(21 \mathrm{~d})$ and $M$. rosenbergii (41 to $98 \mathrm{~d}$ ). Consequently, the high proportion of individuals in preecdysis in the $R$. exoculata populations has to be interpreted as the result of a drastically shortened anecdysis and a high moulting rate, while the duration of the preecdysis remains similar to that observed in littoral shrimps. In crustaceans, short moult cycles and high moulting rates are generally related to a high metabolism in warm-water species (Charmantier-Daures \& Vernet 2004). General considerations on hydrothermal vents would suggest that $R$. exoculata faces high environmental temperatures but recent investigations on its chemical and thermal environment indicate that temperatures within shrimp swarms do not commonly exceed $14^{\circ} \mathrm{C}$ and the ambient life temperature is approximately $8.7^{\circ} \mathrm{C}$ (Geret et al. 2002, Zbinden et al. 2004). Thus, the apparent moulting rate and high metabolism of $R$. exoculata cannot be related exclusively to extreme conditions such as a warm environment, but can be more specifically be interpreted as a close relationship with the bacterial ectosymbiosis.

\section{Bacterial colonisation}

The present microscopic observations of the vent shrimp Rimicaris exoculata show a real synchronism between the moult and the progress of the ectosymbiosis throughout the moult cycle, and reveal the re-start of a new bacterial community on 'free' surfaces of the new cuticle after each exuviation. In addition, the settlement and development of the bacterial cover appear to be a gradual progression of bacterial proliferation and mineral deposition between 2 successive exuviations.

According to the time-scale from the extrapolated moult cycle duration in $R$. exoculata, bacterial colonisation appears to start with the first patches of bacterial cells (rods and short filaments) only hours after exuviation and progresses very quickly to form a complete cover probably within $2 \mathrm{~d}$ (estimated duration for stages $\mathrm{A} / \mathrm{B}$ to $\mathrm{C}_{4}$ ). This timescale seems to agree with the common growth rates of bacteria in culture (Payne $\&$ Wiebe 1978). Different hypotheses can be proposed to explain the origin of the bacteria, which must be reacquired after each exuviation. First, the gill chamber may be re-colonised naturally by environmental bacteria from the substrate close to the shrimp swarms. The free gill chamber in newly moulted individuals could represent an advantageous micro-environment for their proliferation (Segonzac et al. 1993). However, because of the high shrimp density in the swarms and the relative scarcity of bacterial mats on the chimneys, this possibility appears rather doubtful (Gebruk et al. 1993). Another way may be the horizontal transfer of bacterial symbionts in the shrimp population through dissemination cells which generally occur in filamentous bacteria (Ghiorse 1984). Finally, the ingestion of the old cuticle with ectosymbionts by other shrimps (see below) could also be considered as an alternative recolonisation and horizontal transfer mechanism, preserving the diversity of bacterial ectosymbionts.

Detailed observation of about 20 ind. never revealed any regression of the bacterial cover or any trace of scraping by mouth appendages (Gebruk et al. 1993, Rieley et al. 1999). The large scaphognathites of Rimicaris exoculata act as gill-cleaners by their regular beating and their long posterior setae (Zbinden et al. 2004) which keep the gills and the corresponding area of the branchiostegite bacteria-free. In contrast, the whole anterior part of the branchiostegite is covered by ectosymbionts. Thus, cleaning or antifouling mechanisms are efficient in $R$. exoculata but are not targeted on the anterior part of the branchiostegite where bacterial colonisation occurs. These observations contradict the idea that the $R$. exoculata feeds directly on symbionts by collecting and ingesting them from their own integument (Gebruk et al. 1993, Rieley et al. 1999). 
Moulting, followed by eating the exuvium along with the symbionts, could also be a way to feed on the bacterial community bred in the gill chamber. Indeed, cuticle fragments, iron oxides and ghosts of bacteria have been found together in the digestive tract of some shrimps (M. Zbinden \& P. Compère, unpubl. data). However, such use of the moult as the main source of nutrition for Rimicaris exoculata seems unlikely because the energy expenditure involved in moulting appears disproportionate to the benefit of organic matter provided by the bacteria. Moreover, cuticle fragments have been found in the digestive tract of anecdysial individuals that were far from the moult stage, while individuals close to ecdysis (late-preecdysial and early postecdysial) do not eat and their digestive tract is generally empty. This suggests that the exuvium with the symbionts is not ingested by shrimps that have moulted, but rather by other individuals in the population. Thus, for $R$. exoculata, eating the exuvium must be no more than a means of reducing the loss of organic and/or mineral matter through the moult, as happens in other crustaceans (Swift 1992, Steel 1993).

Some authors consider that, in many crustaceans, a high moulting rate can be regarded as an antifouling mechanism contributing to the elimination of epibiotic bacteria (Bauer 1989). In Rimicaris exoculata, microscopic and macroscopic observations rather suggest that shrimp and bacteria maintain a close ectosymbiotic relationship. The short moult cycle and high moulting frequency in $R$. exoculata are most likely a means of periodically renewing an aging ectosymbiont community. Indeed, the mineral deposits closely associated with the bacteria continuously accumulate until the late preecdysial stages to form a thick mineral crust. This mineral crust may thus act as a barrier, reducing exchanges and increasing the diffusion distance between the underlying bacterial community and the ambient seawater. The uptake of energybearing molecules from hydrothermal fluid could thus be reduced, limiting bacterial metabolism. In this way, a high moulting rate could be regarded as an antifouling mechanism that eliminates the mineral crust to allow the reinstallation of a new and efficient symbiotic community.

\section{Mineral deposition and colour changes}

Zbinden et al. (2004) consider iron oxide as an end product of the metabolism of iron-oxidising bacteria as it favours iron oxide precipitation by oxidising $\mathrm{Fe}^{2+}$ in $\mathrm{Fe}^{3+}$ ions. Observation of Rainbow and TAG shrimps reveals that the formation of the first iron oxide particles occurs after bacterial colonisation (Stages $\mathrm{D}_{0}-\mathrm{D}_{1}$ ), inside the bacterial cover, in close contact with the bac- teria, and thus seems to depend on the presence of bacteria and/or bacterial activity (Fortin \& Langley 2005).

Our results suggest that the gradual accumulation of iron oxides in the shrimp gill chamber until ecdysis is directly responsible for the shrimp colour changes from light to dark red according to their moult stage. At late preecdysis, the oxides form a thick mineral crust covering most of the inner branchiostegite cuticle. Regarded as the final step of deposition, this crust is roughly organised into 3 levels, summarising the successive steps in crust formation and particle growth. Obviously, the nucleation of new iron oxide particles occurs continuously in the lower level just above the cuticle, which is rich in bacteria and a probable site of bacterial growth and iron-oxidising activity. In the median level, the mineral particles gradually increase in size, probably by accretion process (Crundwell 2003, Chan et al. 2004). In the upper level, the large particles continue to grow, extending at the edges, until they meet adjacent particles but they do not fuse. They finally form a compact layer of disconnected and closely spaced polyhedral elements with deep indentations. Thus, to account for such a 3-level mineral crust formation, we suppose that iron oxide particles are continuously produced from beneath, in close association with the bacterial population in the lower level. The crust forms and thickens, as the older particles gradually increase in size and are simultaneously shifted upwards, most probably pushed by the growth of the subjacent bacterial population.

In shrimps from the TAG site, we showed that grey shrimps intercalate between white and light red shrimps in the moult cycle. The grey colour seems to correspond to fine grey deposits of iron sulphide on the bacterial biofilm (Gebruk et al. 1993). Although the iron oxide deposits are preceded by iron sulphide in TAG shrimps, deposition and crust formation occur in very similar fashion in the shrimps from both Rainbow and TAG sites. The only difference is the lower proportion of dark red shrimps from TAG with a thick mineral crust in their gill chamber. This observation could be directly related to the lower concentration of iron in the hydrothermal fluid from TAG $(5 \mathrm{mM})$ compared to Rainbow (24 mM) (Douville et al. 2002, Schmidt et al. 2007).

\section{CONCLUSIONS}

This is the first study to use the moult cycle as a time scale to track the development of bacterial ectosymbiosis and its associated minerals in the gill chamber of the hydrothermal vent shrimp Rimicaris exoculata. The growth of the bacterial community and the gradual 
deposition and accumulation of iron oxide in the gill chamber are directly related to the apparent colour of the shrimps, which evolves from white (no mineral) to dark red (heavily mineralised) from postecdysis to preecdysis, respectively. In addition, the close correspondence between 2 successive exuviations provides a rapid macroscopic method for stage estimation of shrimps from the Rainbow and TAG sites.

Determining the metabolism of the Rimicaris exoculata symbiotic bacteria represents a great challenge. While waiting to characterise these bacterial strains in culture, studying the associated minerals remains an important investigation route to determine their final products. While the development and organisation of the iron oxide mineral crust into 3 levels suggests the presence of iron-oxidising bacteria, many questions nevertheless remain as to the exact nature of the mineral particles, their nucleation and their growth in relation to the bacteria.

Acknowledgements. The authors thank A. Godfroy, chief scientist of the EXOMAR cruise as well as the captain and crew of the RV 'Atalante' and the ROV 'Victor' team. The authors also express their appreciation to N. Decloux for her excellent technical assistance. This work was partly funded with the help of the MOMARNET program. The fellowship of L.C. and a part of this work were supported by the Belgian Fund for Joint Basic Research (FRFC Belgium, Conventions nos. 2.4533.01.F and 2.4594.07.F).

\section{LITERATURE CITED}

Andrieux N (1979) L'apolyse au cours du cycle d'intermue de deux crustacés Décapodes Brachyoures, Carcinus maenas Linné et Carcinus mediterraneus Czerniavsky. CR Acad Sci Paris 288:1595-1597

Bauer RT (1989) Decapod crustacean grooming: functional morphology, adaptive value, and phylogenetic significance. In: Felgenhauer BE, Watling L, Thistle AB (eds) Functional morphology of feeding and grooming in Crustacea. Balkema, Rotterdam, p 48-73

Benayoun G, Fowler SW (1980) Long-term observations on the moulting frequency of the shrimp Lysmata seticaudata. Mar Biol 59:219-223

Bottrell HH (1975) Generation time, length of life, instar duration and frequency of moulting, and their relationship to temperature in eight species of cladocera from the River Thames. Oecologia 19:129-140

Casanova B, Brunet M, Segonzac M (1993) L'impact d'une épibiose bactérienne sur la morphologie fonctionnelle de crevettes associées à l'hydrothermalisme médio-Atlantique. Cah Biol Mar 34:573-588

Cavanaugh C, McKiness Z, Newton I, Stewart F (2006) Marine chemosynthetic symbioses. In: Dworkin $M$, Falkow S, Rosenberg E, Schleifer K, Stackebrandt E (eds) The prokaryotes. Springer, New York, p 475-507

Chan CS, De Stasio G, Welch SA, Girasole M and others (2004) Microbial polysaccharides template assembly of nanocrystal fibers. Science 303:1656-1658

Charmantier-Daures M, Vernet G (2004) Moulting, autonomy and regeneration. In: Forest J, Van Vaupel Klein JC (eds)
Treatise on zoology, 1. Anatomy, taxonomy and biology, Vol. 1: Crustacea. Koninklijke Brill, Leiden, p 161-254

Compère $P$, Jeuniaux $C$, Goffinet $G$ (2004) The integument: morphology and biochemistry In: Forest J, Van Vaupel Klein JC (eds) Treatise on Zoology, 1. Anatomy, taxonomy and biology, Vol. 1: Crustacea. Koninklijke Brill, Leiden, p 59-144

Crundwell FK (2003) How do bacteria interact with minerals? Hydrometallurgy 71:75-81

Desbruyères $\mathrm{D}$, Biscoito $\mathrm{M}$, Caprais $\mathrm{JC}$, Colaco $\mathrm{A}$, Comtet $\mathrm{T}$, Crassous P, Fouquet Y, Khripounoff A, Le Bris N, Olu K (2001) Variations in deep-sea hydrothermal vent communities on the Mid-Atlantic Ridge near the Azores plateau. Deep-Sea Res A 48:1325-1346

Douville E, Charlou JL, Oelkers EH, Bienvenu P and others (2002) The rainbow vent fluids $\left(36^{\circ} 14^{\prime} \mathrm{N}, \mathrm{MAR}\right)$ : the influence of ultramafic rocks and phase separation on trace metal content in Mid-Atlantic Ridge hydrothermal fluids. Chem Geol 184:37-48

Drach P (1939) Mue et cycle d'intermue chez les Crustacés Décapodes. Ann Inst Oceanogr Paris (Nouv Ser) 19: 103-391

Drach P, Tchernigovtzeff C (1967) Sur la méthode de détermination des stades d'intermue et son application générale aux crustacés. Vie Milieu 18:595-609

Fortin D, Langley S (2005) Formation and occurrence of biogenic iron-rich minerals. Earth Sci Rev 72:1-19

Gebruk A, Pimenov N, Savvichev A (1993) Feeding specialization of bresiliid shrimps in the TAG site hydrothermal community. Mar Ecol Prog Ser 98:247-253

Geret F, Riso R, Sarradin PM, Caprais JC, Cosson R (2002) Metal bioaccumulation and storage forms in the shrimp, Rimicaris exoculata, from the Rainbow hydrothermal field (Mid-Atlantic Ridge); preliminary approach to the fluidorganism relationship. Cah Biol Mar 43:43-52

Ghiorse WC (1984) Biology of iron- and manganese-depositing bacteria. Annu Rev Microbiol 38:515-550

Gloter A, Zbinden M, Guyot F, Gaill F, Colliex C (2004) TEMEELS study of natural ferrihydrite from geological-biological interactions in hydrothermal systems. Earth Planet Sci Lett 222:947-957

Hessen DO, Alstad Rukke N (2000) The costs of moulting in Daphnia; mineral regulation of carbon budgets. Freshw Biol 45:169-178

Lindquist RM (1975) Molting in stomatopod crustaceans. I. Stages of the molt cycle, setagenesis, and morphology. J Morphol 146:55-80

Payne WJ, Wiebe WJ (1978) Growth yield and efficiency in chemosynthetic microorganisms. Annu Rev Microbiol 32: 155-183

Polz MF, Cavanaugh CM (1995) Dominance of one bacterial phylotype at a Mid-Atlantic Ridge hydrothermal vent site. Proc Natl Acad Sci USA 92:7232-7236

Polz MF, Robinson JJ, Cavanaugh CM, Van Dover CL (1998) Trophic ecology of massive shrimp aggregations at a MidAtlantic Ridge hydrothermal vent site. Limnol Oceanogr 43:1631-1638

Pond D, Bell M, Dixon D, Sargent J (1997) Occurrence of 16:2(n-4) and 18:2(n-4) fatty acids in the lipids of the hydrothermal vent shrimp Rimicaris exoculata: nutritional and trophic implications. Mar Ecol Prog Ser 156:167-174

Rieley G, Dover CLV, Hedrick DB, Eglinton G (1999) Trophic ecology of Rimicaris exoculata: a combined lipid abundance/stable isotope approach. Mar Biol 133:495-499

Schmidt K, Koschinsky A, Garbe-Schonberg D, de Carvalho LM, Seifert R (2007) Geochemistry of hydrothermal fluids from the ultramafic-hosted Logatchev hydrothermal field, 
$15^{\circ} \mathrm{N}$ on the Mid-Atlantic Ridge: temporal and spatial investigation. Chem Geol 242:1-21

Segonzac M, de Saint-Laurent M, Casanova B (1993) L'énigme du comportement trophique des crevettes Alvinocarididae des sites hydrothermaux de la dorsale médio-atlantique. Cah Biol Mar 34:535-571

Shillito B, Le Bris N, Gaill F, Rees JF, Zal F (2004) First access to live Alvinella. High Pressure Res 24:169-172

Steel CG (1993) Storage and translocation of integumentary calcium during the moult cycle of the terrestrial isopod Oniscus asellus (L.). Can J Zool 71:4-10

Swift DJ (1992) The accumulation of plutonium by the European lobster (Homarus gammarus L.). J Environ Radioactiv 16:1-24

Van Dover C, Fry B, Grassle F, Humphris S, Rona PA (1988) Feeding biology of the shrimp Rimicaris exoculata at

Editorial responsibility: Judith Grassle,

New Brunswick, New Jersey, USA hydrothermal vents on the Mid-Atlantic Ridge. Mar Biol 98:209-216

Williams A, Rona PA (1986) Two new Caridean shrimps (Bresiliidae) from a hydrothermal field on the mid-Atlantic Ridge. J Crustac Biol 6:446-462

Wirsen CO, Jannasch HW, Molyneaux S (1993) Chemosynthetic microbial activity at Mid-Atlantic Ridge hydrothermal vent sites. J Geophys Res 98:9693-9703

Zbinden M, Cambon-Bonavita MA (2003) Occurrence of Deferribacterales and Entomoplasmatales in the deep-sea Alvinocarid shrimp Rimicaris exoculata gut. FEMS Microbiol Ecol 46:23-30

Zbinden M, Le Bris N, Gaill F, Compère P (2004) Distribution of bacteria and associated minerals in the gill chamber of the vent shrimp Rimicaris exoculata and related biogeochemical processes. Mar Ecol Prog Ser 284:237-251

Submitted: July 27, 2007; Accepted: December 5, 2007 Proofs received from author(s): January 8, 2008 